Article

\title{
Jawdat Sa id and the Islamic Theology and Practice of Peace
}

\author{
Rüdiger Lohlker (D)
}

check for updates

Citation: Lohlker, Rüdiger. 2022. Jawdat Sacid and the Islamic Theology and Practice of Peace. Religions 13: 160. https://doi.org/ 10.3390/rel13020160

Academic Editors: Ephraim Meir, Ed Noort, Louise du Toit and Wolfgang Palaver

Received: 29 December 2021

Accepted: 9 February 2022

Published: 11 February 2022

Publisher's Note: MDPI stays neutral with regard to jurisdictional claims in published maps and institutional affiliations.

Copyright: (C) 2022 by the author. Licensee MDPI, Basel, Switzerland. This article is an open access article distributed under the terms and conditions of the Creative Commons Attribution (CC BY) license (https:// creativecommons.org/licenses/by/ $4.0 /)$.
Oriental Institute, Vienna University, 1010 Vienna, Austria; ruediger.lohlker@univie.ac.at

\begin{abstract}
Among the leading Islamic thinkers and activists promoting a theology of peace based on the Qur'anic revelation is Jawdat Sa'id. Framing his role by an analysis following the conceptualization of Shahab Ahmed the Qur'anic context of the ideas of Sa id are presented, and these ideas are contextualized within the recent Syrian revolution before it turned into civil war. Fundamental ideas of the theology of Sa id help to explain the thoughts of a lesser known activist of nonviolent action based on a specific and revolutionary interpretation of the Qur'an.
\end{abstract}

Keywords: Jawdat Sa id; Syria; nonviolence; Islam; Abel; Cain

\section{Introduction}

The violent turn of the Syrian revolution has often been described; the nonviolent activism, of more importance, at the beginning of it has been less described. A driving force during the early period were local committees (Perlman 2019), e.g., the Local Coordination Committees (Marei 2020). These committees created a new national community (cf. Ismail 2011) that may be compared to the new communities envisioned by Jawdat Sa'id (cf. below). Sa'id was an important thinker inspiring the nonviolent beginnings and local committees whose influence reached out well beyond Syria. Jawdat Sa'id and his recent role in the Arab and Islamic world have to be understood in the context of the Syrian Revolution ${ }^{1}$ :

"The Syrian Revolution began nonviolently. The vast majority of participants maintained nonviolence as their path to pursue regime change and a democratic Syria, until an armed flank emerged in August 2011. Since then, the revolution has morphed. The original uprising began at the grassroots, and solidarity across lines of sect, religion, and ethnicity was strong among the grassroots population. However, from midsummer to autumn, 2011, armed resistance developed; political bodies formed to represent the revolution outside Syria; and political Islamists of various sorts entered the uprising scene. Since then, armed resistance has overshadowed nonviolent Syria. It should not be a surprise to find that nonviolent resistance diminishes after the emergence of an armed resistance. What is remarkable is that nonviolent resistance in Syria has continued, despite being overshadowed by the raging battle between the regime and the militarized flank of the revolution, and despite being beleaguered by tensions with the armed resistance." (Kahf 2014, pp. 1-2)

To include the influence of Jawdat Sa id on the early Syrian revolution in our considerations, we have to mention that in 1998, the town of Daraya in the countryside of Damascus took Sa'id's ideas about nonviolence as a starting point for their activities. However, in 2003, these young people were targeted by governmental persecution. The members of this group organized a series of multicultural seminars on nonviolence in the city of Homs. Their collective was not a religious one but spiritual-ethical and intersected with the circles of the followers of Sacid (Kahf 2014, p. 1).

The nonviolent way of actions in this Syrian revolution was inspired-among other factors-by the ideas of Jawdat Sacid. The opening sentence of the main page of this Syrian 
thinker and author reads: "We live in a world in which four-fifths of its population live in frustration while the other fifth lives in fear." 2 Thus, we may not talk about ideas but about a practical perception of the world based on the need to erase inequalities affecting our societies leading to violence.

There are few studies on this Syrian author and activist who has a unique position in contemporary Islam (Müller 2010; Kahf 2014; Lohlker 2016; Murtaza 2016; OllivryDumairieh 2016; Rak 2016; Belhaj 2017; Zecca 2020). As an activist, he participated in the nonviolent opposition in Syria in 2011. In 2013, he had to migrate to Turkey. His writings, however, are still read in the Arab world (and sometimes beyond).

The corpus we are using for our analysis is the comprehensive set of original writings and videos at jawdatsaid.net. To give an overview, we may mention (a) several books, (b) many articles, (c) videos (e.g., lectures illustrated with background pictures), (d) audio files (most of them from 2007 and 2008), (e) other articles in journals, (f) interviews in journals, and g) contemporary Islamic issues. Some books in English and French are available, but the bulk of the material is written and produced in Arabic.

Methodologically speaking, this study of the ideas of Jawdat Sa id performs a close reading of selected texts by Sa id to explore his way of thinking. These texts are framed by the approach developed by Shahab Ahmed (cf. below). The style of this article is rhizomatic (cf. Lohlker 2021, p. 122), allowing for a precise presentation and reconstruction of the ideas of Sa id using the quotations as points of intersection between the ideas presented. We are aware that may be not understandable to readers expecting conventional narratives, but this way of presenting Sa id is well in line with advanced philosophical approaches and sampling as a method of artistic research (cf. Navas 2012).

\section{Biography}

Who is Jawdat Sa id? The best short biography was written by $\mathrm{Crow}^{3}$ :

"Jawdat Sa'id was born in 1931 in the Circassian village of Bi'r 'Ajam, south of Qunaytra in the Golan Heights. His family (named Tsai) was part of the wave of Circassian immigration from Russian territory into the Arab provinces of the Ottoman empire in the late nineteenth century. At the age of fifteen he was sent to study in Cairo at the prestigious Al-Azhar University, graduating in 1957 with both a university degree in Arabic literature and a diploma in education. After returning to Syria he taught for over ten years, first in the Dar al-Mu'allimin (Teachers' College) in Damascus and then in high schools in and around Damascus, including teaching "morale" in military schools (e.g., in the city of Homs in central Syria). Increasingly, he found himself demoted to less prestigious schools. In 1968, Sa id was dismissed from his government employment as a teacher, due to his advocacy of ideas on Islamic peace and their implications for radical social transformation, for his published views (his first book appeared in 1966), and for his activism through lecturing in mosques, civic centers, and within Syrian intellectual and social circles. In 1968 he was imprisoned by the Syrian authorities for a year and a half. He has been to prison under the $\mathrm{Ba}^{\prime}$ th regime five times, usually for periods of several months, the last time being in 1973. During the early 1980s, when the Syrian Ikhwan alMuslimin (Muslim Brethren) were actively opposing President Asad's regime, he was often interrogated and watched, although he has never been a member of the Muslim Brethren. For well over a decade he chose to live in voluntary internal exile, working in Tolstoy-like fashion at his family's apiary in Bi'r 'Ajam. This exemplifies his conviction that intellectual freedom must be linked to gainful work. His withdrawal from active social engagement, coinciding with the clash between the Islamist opposition and the Syrian government, was motivated by his understanding of the Islamic requirement to avoid fitnah or civil discord and violence. Since the early 1990s, Sa id has gradually become more active within Syria, cultivating contacts and engaging in dialogue with a wide spectrum of 
religious, political, and social trends within the Sunni religious establishment [ ... ], with Communists, Arab nationalists, and the Union of Arab Writers [...]. This reflects Sa id's commitment to accepting other viewpoints, fostering a more secure sense of community and common purpose among Arab Muslims, and tolerating the pursuit of different directions in finding solutions." (Crow 2000, pp. 64-65)

His stay in Egypt from 1946 to 1958 was (cf. below) crucial for the intellectual development of Sa'id. Important writers influencing him were Abu A'la Mawdudi (d. 1979 CE), Jamal al-Din al-Afghani (d. 1897 CE), Muhammad 'Abduh (d. 1905 CE), Rashid Rida (d. 1935 CE), Jalal al-Din Rumi (d. 1273 CE), Ibn Qayyim al-Jawziyya (d. 1350 CE), Ibn Taymiyya (d. 1328 CE), Abu Hamid al-Ghazali (d. 1111 CE), Ibn Rushd (d. 1198 CE), and Ibn Khaldun (d. 1406 CE), i.e., many of the important thinkers of Sunni Islam. More important were Muhammad Iqbal (d. 1938 CE) and Malik Bennabi (d. 1973 CE), two of the most influential thinkers of the modern Islamic world.

After staying in Egypt, he traveled to Saudi Arabia and then the United Arab Republic of Egypt and Syria; then he traveled to Iraq, India, and Pakistan. Thus, he gained first-hand knowledge of many parts of the Islamic world. He also met the influential Islamic scholar Abul Hasan 'Ali Nadvi (d. 1999 CE) in India. Thus, we may sketch his influences before finally returning to Syria (cf. above). ${ }^{4}$

\section{A Shahabian Approach}

We will situate the ideas and practice of Jawdat Sacid in the Con-Text of revelation. Following Shahab Ahmed, this hermeneutical engagement is based on the previous hermeneutical engagement being present as Islam (cf. Ahmed 2016, p. 356). Ahmed writes:

"Con-Text is thus the entire accumulated lexicon of means and meanings of Islam that has been historically generated and recorded up to any given moment: it is the full historical vocabulary of Islam at any given moment. When a Muslim seeks to make meaning in terms of Islam, he necessarily does so in engagement with and by use of the existing terms of engagement - that is, in engagement with and by use of the existing vocabulary of Islam. The vocabulary of Islam registers, denotes and makes available the meanings of previous hermeneutical engagement; the meanings of previous hermeneutical engagements are, in other words, discernibly embedded in the semantic units of this existing vocabulary of forms. Thus, in a given time or place, for the meaning of an act or utterance to be recognizable in terms of Islam it must be expressed in the vocabulary of Con-Text." (Ahmed 2016, p. 357)

Other important terms for the analysis of Ahmed are Pre-Text and Text. Pre-Text is not to be understood as chronologically prior to the Text of the revelation/the Qur'ān; it is ontologically and alethically before it but encompasses "the Unseen Pre-Text of the Revelation" (Ahmed 2016, p. 347) as being continuously present in the world and in Islam. The hermeneutical engagement with the Text/the Qur'ān takes place in the world of the Unseen of the Pre-Text and is made livable in the Con-Text. The Con-Text can be attributed and traced to the Text and Pre-Text and provides the web of meaning(s) by which Muslims live their hermeneutical engagement with Revelation (Ahmed 2016, pp. 358-59)

Taking up this framework, we may start to analyze the ideas and practice of Jawdat Sa id as an example of hermeneutical engagement with the Revelation. In the context of modern Islamic thought in the Arab world, his position is specific but present until today, contrary to the impression that violent and fundamentalist ideas are dominating the field of discussion.

Returning to the problem of societal change addressed in the beginning, we may refer to Zecca, who wrote in her review of an anthology of translations of writings of Jawdat Sacid in Italian that his ideas may be analyzed as a reaction to the conditions of the contemporary Arab world and its despotic regimes. Hence, change of this situation is a core idea of Sa'id: 
"Sacid defends the possibility of a pacific change which should establish democratic political systems based upon human rights. It is impossible, according to Sa id, for war to be a vector of change, especially because he considers violence, as a mode of action, anachronistic in relation to the evolution of humanity within our time. It defines the man who resorts to violent action as someone who lives in an 'abrogated time'. He compares young men sent to war to the human sacrifices of ancient populations [ ...] and, referring to the endless status of war of the Arab states, he underlines the stupidity of governments who continue to buy weapons from Occidental companies in order to fight one against the others [ ...]. Appealing to the unity of the Muslim world, Sa id exhorts to the end of arms trade, also comparing weapons to fetishes of the Jahiliyya (pre-Islamic or ignorance) period [ ... ]." (Zecca 2020, p. 215)

These remarks hint at the subterranean linkages of the ideas of Jawdat Sacid to the Arab revolutions after 2010, mentioned before. Hence, the impact of Jawdat Sa id was the need to change the situation of Arab societies and the Islamic world. To develop this idea, he began to rethink shared notions of what being Islamic means.

During and after his stay in Cairo at the al-Azhar university, he was deeply involved in the contemporary discussion in the Arab and Islamic world. His main persons of reference were Muhammad Iqbal (Hillier and Koshul 2015; Majeed 2009) and Malik Bennabi (Seniguer 2014; Sherif 2018). Unlike the move of Syrian opposition toward a violent strategy in the 1960s, he published his first book in the year 1966 when Sayyid Qutb, famous for his book Milestones, a programmatic work of the first wave of modern violent Jihadism, was executed. Sa'id's book may be read as an answer to this text that was based on the experience of the repressive regime in Egypt (cf. below). A writer and activist in a likewise repressive context in Syria was able to create a theory of nonviolence understood as an integral part of Islam. This may be proof that the results of the hermeneutic engagement with the Qur'anic revelation may be even contradictory, as Shahab Ahmed wrote.

\section{The Path of Adam's First Son}

The first book of Jawdat Sa ${ }^{1}{ }^{5}$ we mentioned is The Path of Adam's First Son: The Problem of Violence in Islamic Activism (cf. Menghini 2019, p. 58; Sa'id 1993). In another text, Sacid mentioned that the first he publicly spoke about The Path of Adam's Son ${ }^{6}$ was in 1965 during the Friday prayer during the month of Ramadan. He describes the emergence of this idea during his time as a student at the University of al-Azhar, where he experienced the incertitude and upheaval of the Arab and Islamic world (Sa id n.d.). Which kind of theory emerged from this situation? The relationship of law and religion in the Muslim community has to be constructive and dynamic. It should not follow the method of imitation and blind acceptance (taqlid) that, for Sa id, has been a decisive factor of the decline of the Islamic world as a whole.

"In this case Sacid was strongly influenced by another great Muslim thinker of Jewish descent Muhammad Asad (1900-1992), who commented in his highly acclaimed book Islam at the Crossroads, that whereas Islam was a perfect system for mankind, it was its believers who failed to live according to its message.

One recurring theme in Sa'id's thought is the need to observe laws, which constitute a profound part of knowledge, he believes. He particularly strongly stresses the notion of change which needs to occur, quoting the Qur'ān: Verily never will God change the condition of a people until they change that what is in their souls. Law allows duties, obligations, and freedoms to be established, but it is injustice that destroys societies. It is humans that are faulty, not the law itself. Law is supposed to protect everyone. In the cycle of history, people relinquish their right to protection and leave it to the law. Sa id warns that when a person gets his right to self-protection, by which he means any kind of violent means, the individual once again becomes part of the law of the jungle, force. Law on the other hand is 
opposed to violence. The question one needs to ask is when exactly did the shift between the law of violence and dialogue take place?" (Rak 2016, pp. 35-36)

The theory he presents is to be found in his book The First Son of Adam. We will follow the presentation of Rak. The starting point of the book is the story of Cain (Qabil) and Abel (Habil) as told in the Qur'an-another case of hermeneutic engagement with the text of the revelation. It reads:

"And recite unto them, with truth, the account of Adam's two sons, when they offered a sacrifice, and it was accepted from one of them, though not accepted from the other. One said: 'I will surely slay you!' [The other] said: 'God accepts only from the reverent. Even if you stretch forth your hand against me to slay me, I shall not stretch forth my hand against you to slay you. Truly I fear God, Lord of the worlds. I desire you should be burdened with my sin and your sin and so become one of the inhabitants of the fire. Such is the recompense of the wrongdoers.' Then his soul prompted him to slay his brother, and he slew him, and thus became to be among the losers. Then God sent a crow, scratching the earth, to show him how he might conceal his brother's nakedness. He said, 'Oh, woe unto me! Am I not able to be even as this crow and conceal my brother's nakedness?' And he came to be among the remorseful." (Sura 5, al-mā'ida, pp. 27-31) $)^{8}$

Abel refraining from slaying his brother materialized the philosophy of nonviolence so dear to Sa'id. The ultimate result of Cain slaying Abel is the grief and sorrow of Cain as described by Sa'id. Thus, Habil brings the historical shift in human behavior by not acting violently.

"Humanity arises from violence, the period of muscles-as Sa id states-to the period of mind and comprehension, leading it to grant moral values a growing presence in one's actions. The choice between the right and wrong actions is still voluntary, but in Abel's choice to act against violent methods one can notice the introduction of the law of dialogue, openness to the Other that is visible in acts of moral responsibility, which is one of the key factors driving human nature in its decisions. A different decision, that made by Abel, would only bring human regression. God by creating people and granting them the role of being His viceregents on earth expects that humankind will finally start acting according to the role that is presented to them. The shift in authority, first based on violence, later leads to comprehension. Sacid sees this as an evolution from the law of the jungle to the law of understanding. This behaviour is full of trust in human evolution. Violent actions are perceived as a form of regression understood as blasphemy, which is considered a major crime in Islam because it means acting against nature and God's order." (Rak 2016, p. 36)

For Sa'id, knowledge and nonviolence is to be understood from a Qur'anic perspective. However, it is necessary to move beyond the realm of texts and include the historical experiences of humanity. Yet he understands the human fallibility and tendency to misinterpret, especially, the messages of the prophets. However, experience may help to find a way out. Sa'id argues for the need for a diversity of readings. Following the example of the ancestors would lead to what is called taqlid, blind acceptance of former views, restricting openness, diversity, and progress in Muslim thought. He points to Iqbal's idea of the difference between religion and the human understanding of religion. Experience is vital to a true understanding of religion (Rak 2016, p. 38). The concept of the need for experience may be regarded as another Islamic legitimation of nonviolent activism conceptualized by Sa'id to create a new history. Sa'id shies not away from controversial points when criticizing the Muslim orthodoxy. Racism or ethnocentrism stem, according to Sa'id, from the denial 
"of the possibility of prophecy to other religious and cultural figures. It is interesting to note the many quotations he himself uses throughout his writings from other than Islamic sources." (Rak 2016, p. 39)

Two important other concepts are equity and justice. Equity is for Sa id the perfect realization of tawhid or believing in one God and unity, a narrow path. ${ }^{9}$ Justice, on the other hand, is best exemplified by the Qur'anic saying "There is no coercion in religion." (cf below).

"Equity for him means no more than the process of denunciation of tyranny and the act of prohibiting religious coercion. It is interesting to note that Sa id sees tyranny as a specific case of breaching the teachings of Islam-and calls it an example of polytheism, an unforgivable sin. According to Said, the call for equality is vital for human prosperity. The main problem of mankind is connected to the rejection of the need for equality, or equity, which can give some people the feeling of superiority, a nearly godlike position among others. This superiority is embedded in the arrogance of people, which is an obstacle not only in building everyday relations but, in the believers' eyes, may also prevent one from entering paradise in the hereafter." (Rak 2016, p. 39)

Rak sketches the concept of Malik Bennabi that there is a certain state of mind or the conditio humana allowing for the emerging of a disposition to be colonized. This state of mind creates the conditions for being colonized. The root causes are the weakness and apathy emerging in Arab societies including the loss of communities dispersed into assemblies of individuals (cf. below). For Sa id, the vital element of the story of Habil he refers to is the ability to end oppression and to build a new society based on equal rights. To use an argument of Sa'id (1993), nonviolence means a shift to the nervous system from the muscular system. The main example for Sa id are the prophets addressing the minds of people and not their bodies. This means that no physical actions are needed (Rak 2016, p. 40). Physical action will be needed when change to a nonviolent society has to take place (cf. below).

Nonviolence is, for Said, an act and idea of freedom since it can be traced back to disobedience, "the negation of the need to take harmful action against another. A disobedience to the culture of muscles as he calls it" (Rak 2016, p. 40). Not engaging in violence is the final proof of intellectual freedom.

\section{Change}

Sacid stresses the need for individual and societal change in his book referring in its title to sura 13, al-rac $d, 11$ : "Truly God alters not what is in a people until they alter what is in themselves." 10 The title is: Until They Alter What Is in Themselves. ${ }^{11}$ The interdependence of individual and collective change as spiritually inspired is described by Sa id as a dual change. The first change is that instilled by God in his creation; the second one, that of the humans, is inspired by God, "a gift from God". Humans will be able to realize this inspiration when they are willing (cf. below) to change themselves. The change, however, is relevant for the individuals. It is a collective change of an entity composed of these individuals.

In this book, Sa id directly criticizes some thoughts of Sayyid Qutb, one of the forefathers of modern-day Jihadism. This indicates the involvement of Sa id in the ongoing discussions in the Arab and Islamic world of this period. Sayyid Qutb may be regarded as the paragon of the movement advocating the use of force and coercion against all other Muslims and non-Muslims.

The denial of coercion ( $i k r a \bar{h})$ is - as mentioned before-crucial for The Path of the First Son of Adam. This concept is further discussed in other texts that may help us understand the hermeneutic engagement of Sa'id with the Qur'anic revelation and to situate him in the contemporary landscape of Islamic discourses 


\section{Lā ikrāh fi ‘d-dīn}

A Qur'anic verse discussed by Sa id especially is Sure 2, al-baqara, 256. Usually, the shortened version is used: "There is no coercion in religion." 12

"The tempter to error $(t \bar{a} g h \bar{u} t)^{13}$ is the one who brings coercion (ikrāh). Hence, it is ordered not to believe in the tempter. The believers are told to believe in God for whom it is true that there is no coercion in His religion (din). ${ }^{14}$ He is not afraid of suffering defeat from renouncing coercion. He trusts in textual logic (mantiq), in the humans (insān) and in God in whose religion is no kind of coercion.

"As to coercion in religion, the removal of coercion is of its most important chapters, more important than all the other chapters. In particular, politics (siyāsa) based on coercion is no [true] leadership. There is no truth (rushd) but error $(\text { ghayy })^{15}$ and deceit. [ ...] According to the strength of coercion truth is far away and the Shari' ${ }^{16}$ is defective or not existing at all. [ ... ] It may be said that according to the advice of the Qur'an to watch out in the future since adopting coercion ${ }^{17}$ since the history of this issue is pitch-black." (Sa'id 1998)

Since Jawdat Sa'id mentions the West as a paradigm for adopting coercion and making it the source of predominance, we may identify one element of the Pre-Text of this interpretation. The other main element is the tyranny of the contemporary Arab world. The references to the Qur'anic revelation are easily identifiable. These presuppositions and the reference of the Qur'anic revelation enable the believers to make a deliberate choice for the devotion of the Qur'anic injunction to resist oppression and coercion. This kind of resistance is, for Sa id, legitimate if it does not lead to coercion and violence. Hence, these paragraphs make the call to nonviolent resistance based on the Qur'anic revelation visible. The framework for the nonviolent opposition in Syria mentioned at the beginning of this chapter is laid out.

The crucial factors that will enable the change needed in society, especially Muslim societies, are described by Sa'id as a manifold endeavor: work or activism ('amal), will (irāda), ability (qudra), and the application of these principles. They are sketched in a book ${ }^{18}$ called al-'Amal: Qudra wa-Irada or Work as Ability and Will (Sa'id 1984).

\section{Work as Ability and Will}

Since the will to choose a nonviolent path to action without turning to coercion is essential for the theories of Sa'id, we have to turn to this book. Sa'id compares the spirit of God with the will of humans. Thus, he argues:

"This is to demonstrate that the body's spirit is its will; once the will is lost, then the body must die-it decomposes in the same way as the individual body decomposes and reverts to its constituent elements. When the community decomposes, its individuals, having lost the common will, will revert to their primitive interests: struggling to preserve their individual lives, not caring about the development of society. It will be an aggregate of individuals, each unto himself/herself. Indeed, the community comes into being at the time its individuals have wills that go beyond themselves as individuals and encompass the others-It is then that the society begins to exist as a body; and it is then that it is true of it to apply the Verse of the Qur'an: "To every people is a term appointed"; (10:49). It is when this happens that you imagine an ummah with a span of life, like an individual. The bond that brings a society together is a will that unites the individuals: one faith, one aim, one ideal ... An ideal is the spirit of the society." (Sacid 1984, p. 175)

Sa'id's idea of will includes the need to uphold a common will lived in a society inspired by the existence of a community that embodies a super-individual spirit. For Sa'id this community is the Muslim ummah as the ideal community. This ideal community Sa id is talking about is, for him, the nonviolent society he envisions. This community is 
embedded in the Islamic worldview of Sa'id and may be illustrated by one example. Said distinguishes between two groups:

"In Islamic tradition, we contrast two groups, the faqihs (scholars of Islamic legislation and rulings), and the Sufis. The latter identify themselves as the 'people of the will, or sincerity', and they designate the Sufi learner as the 'murid, i.e., the searcher for the Truth'. To them, the illiterate, the most ignorant, can ascend to a supreme level of sincerity and will. I find this a very good application of our theoretical discussion of the will: it indicates that the will can rise to a very high level even in the illiterate and the children, both female and male, as may be attested by their willingness to offer their money and life." (Said 1998, p. 283)

Hence, the will to change the personal life and society to a nonviolent one is open to every human willing to act accordingly. One author writing on Sa id voices some criticism.

\section{Criticizing Sa'id}

Menghini wrote in his article on Sa'id that Sa'id's theory of Habil's path, his contextualization of nonviolence, and his exposition of the revolutionary potential of the Islamic idea of the one God (tawhid) as part of Sa'id's theology of nonviolence allow for a deep understanding of his ideas. Menghini, nevertheless, identifies some points to be criticized concerning his argumentation and practicability. Sa id's selection of passages from the Qur'an and Hadith is not-according to Menghini-sufficiently explained and allegedly arbitrary. Menghini argues that there are other interpretations of these passages available (Menghini 2019, p. 56).

This kind of criticism is an example of a misunderstanding of the creative hermeneutical engagement with the Qur'anic revelation as a defective form of scholarly writing. The way of writing of an Islamic activist and believer is to be understood in internal terms as a coherent set of ideas aiming at establishing a theory of nonviolence based on the Islamic tradition. A criticism of the arbitrariness of the selection of Qur'anic and Hadith passages quote by Sa id reveals a misunderstanding of the hermeneutical approach of Sa'id and is assuming a structure of the Qur'an and Hadith similar to a European novel of the nineteenth century. Furthermore, taking one book as representing all of the thoughts of one author reveals an underlying Orientalist worldview, assuming that the system of being Islamic of this author can be derived from just one source. Menghini is referring to the fundamentalist writer $\mathrm{Abu} \mathrm{A} \mathrm{A}^{\prime}$ la Mawdudi ${ }^{19}$ as presenting another interpretation than Sa ${ }^{\mathrm{id}}$ and ignoring the diversity of Islamic interpretations of sources.

This difference in interpretation demands that Said provide a more structured explanation of the reasoning behind his interpretation of this passage. The same can be said about other passages he chose to include in his argument, especially those where alternative readings suggest that nonviolence may be more of a response to circumstances than conscious adherence to Habil's path. When the Prophet Muhammad, for example, invited Muslims to be patient and not use violence against polytheists in Mecca, the reason could be connected with the equilibrium of forces specific to that moment, more than with a conscious choice of nonviolence. The non-Muslims in Mecca were much stronger than the Muslims, and so the choice to not confront them with force could have been made by a strategic circumstantial justification.

The criticism goes on to assume that Said should have to write a book based on academic definitions. Reading Sacid, we have to bear in mind that these texts (and videos) of an Islamic activist are not academic texts on early Islamic history. The demands that these texts have to follow the rules of another field of intellectual production are absurd. The absurdity is multiplied by other demands for definitions and explanations:

"For instance, when explaining how the distinctive society will be created,

Sa'id does not define what is meant by 'society'. Is this society simply Islamic, or should it be defined in terms of reach on a national or global scale?" (Menghini 2019, p. 57) 
Although we might say that the critique of Menghini may be excused as a published by journal of undergraduate students, it reveals some methodological shortcomings detected in more elaborate scholarly works. Worse, it is one of the few articles analyzing a book of Sa id available. ${ }^{20}$ Thus, this article may be regarded as a paradigmatic case. Nevertheless, Menghini continues:

"the relevance of Sa'id's work is clearly demonstrated in his innovative position on, and interpretation of, the principle of nonviolence. In constructing Habil's path as a new madhhab modeled on the lives of the prophets, Sa'id shows how nonviolence is a recurring theme throughout the history of Islam. As such, he makes a convincing argument that nonviolence is truly an "Islamic" principle. [ ... ] Moreover, Sa id's theorization of nonviolence as a methodology sets him apart from many other philosophers both inside and outside the Islamic world." (Menghini 2019, p. 57)

This leads us to look at the context of Islamic ideas of nonviolence. Despite the overwhelming literature on states, groups, and individuals promoting military Jihad as an Islamic duty, there is a sector of Islamic thought and activism promoting nonviolent activism. We may just mention the Pashtun activist and leader of the Khudai Khidmatgaran Abdul Ghaffar Khan (Easwaran 2002) or the Indian writer Wahiduddin Khan (Omar 2008a, 2008b). For our context, the Syrian writer and activist Afra Jalabi, who integrated the ideas of Jawdat Sa'id in her thought, is important (Jalabi 2018). She is the scion of a family of nonviolent activists.

\section{Conclusions}

Jawdat Sa'id's nonviolent reading of the Qur'an and his engagement with the Qur'anic revelation is a paradigmatic case to illustrate the many ways Muslims can engage with the revelation and-in his case-turn it into a tool for nonviolent activism. ${ }^{21}$ Leaving aside the question of religious truth, the ideas of Sa id maybe the heritage of the beginnings of the Syrian resistance before it was turned into violence and part of the heritage of this historical moment to further the development of nonviolent ideas and practices as a legacy for humanity. It is not a study on Syrian ideas. It is a study on part of the global discussion on nonviolence. Sa id, e.g., has been lecturing in many countries and to global media. ${ }^{22}$ His global approach can be understood by videos on his ideas. Thus, he is a Syrian thinker but not limited to Syria in his worldviews. ${ }^{23}$

Further analysis of Jawdat Sa'id's thinking and practice will have to identify the sources of his ideas and the difference in presentation in writings, audio-visual presentations, commentaries, and other ways to convey his ideas.

Funding: This research received no external funding.

Acknowledgments: Open Access Funding by the University of Vienna.

Conflicts of Interest: The author declares no conflict of interest. The funders had no role in the design of the study; in the collection, analyses, or interpretation of data; in the writing of the manuscript, or in the decision to publish the results.

\section{Notes}

1 We intentionally refrain from trying to give a bibliography of the recent Syrian development since this article is focused on the ideas of one Syrian thinker and activist. The following quotation gives an outline of the Syrian revolution.

2 https://www.jawdatsaid.net/en/index.php/Main_Page (accessed on 14 December 2021).

The best visual biography is Jawdat Sa'id Twitter Channel (2021). The exact birth date given in the video is 31 January 1931.

The video Jawdat Sa'id Twitter Channel (2021) shows a picture of Sa'id reading and a picture of Gandhi at the bookshelves in the background.

5 A study of all publications, interviews, videos, etc. is far beyond the scope of an article. Unfortunately, current research is far away from producing a book-length study that would be needed. However, this article is an overview using carefully selected texts to give an outline of the ideas of Sa id. 

2018, p. 251)

\section{References}

Abu-Nimer, Mohammed. 2001. A Framework for Nonviolence and Peacebuilding in Islam. Journal of Law and Religion 15: 217-65. [CrossRef]

Abu-Nimer, Mohammed. 2018. Islamic Approaches to Nonviolence and Peacebuilding: A Critical Examination. In The Warrior and the Pacifist: Competing Motifs in Buddhism, Judaism, Christianity, and Islam. Edited by Lester A. Kurtz. New York: Routledge, pp. 242-61.

Ahmed, Shahab. 2016. What is Islam? The Importance of Being Islamic. Princeton: Princeton University Press.

al-Marzūqī, Abū Ya'rib, Muhammad 'Adnān Sālim, Ghatafān al-Qādirī, Hidāyat Sālim, Muhammad 'Ammār, Hanān Lihām, Khālis Jalabī, Taysīr al-'Umar, Abū Harb Sahar, Abū Khalīl Shauqī, and et al. 2006. Jawdat Sa'ìd: Buhūth wa-maqālāt muhdāt ilayhī. Damascus: Dār al-Fikr.

Belhaj, Abdessamad. 2017. Jawdat Sa id and the Muslim Philosophy of Peace. In Islamic Peace Ethics: Legitimate and Illegitimate Violence in Contemporary Islamic Thought. Edited by Heydar Shadi. Baden-Baden: Nomos, pp. 231-45.

Crow, Karim Douglas. 2000. Nurturing Islamic Peace Discourse. American Journal of Islam and Society 17: 54-69. [CrossRef]

Easwaran, Eknath. 2002. Nonviolent Soldier of Islam: Badshah Khan. Tomales: Nilgiri Press.

Hillier, H. Chad, and Basit Bilal Koshul, eds. 2015. Muhammad Iqbal: Essays on the Reconstruction of Modern Muslim Thought. Edinburgh: Edinburgh University Press.

Ismail, Salwa. 2011. The Syrian Uprising: Imagining and Performing the Nation. Studies in Ethnicity and Nationalism 11: 538-49. [CrossRef]

Jalabi, Afra. 2018. Making Peace with Islam: The Muslim as Peacemaker. In The Warrior and the Pacifist: Competing Motifs in Buddhism, Judaism, Christianity, and Islam. Edited by Lester A. Kurtz. New York: Routledge, pp. 195-215.

Jawdat Sa'id Twitter Channel. 2021. Jawdat Sa id ... Muqtatafāt min hayātihī wa-fikrih̄̄. Available online: https://www.youtube.com/ watch?v=iISFtEab11Y (accessed on 27 December 2021).

Kahf, Mohja. 2014. Nonviolence in Syria. Fellowship 78: 16-20.

Lohlker, Rüdiger. 2016. Friede-islamische Perspektiven. In Frieden: Vom Wert der Koexistenz. Edited by Clemens Sedmak. Darmstadt: WBG, pp. 203-21.

Lohlker, Rüdiger. 2021. Ibn Taymiyya on Political Leadership and the Con-Text of Philosophy and Law. Wiener Zeitschrift für die Kunde des Morgenlandes 111: 121-36.

Lohlker, Rüdiger. 2022. Religion, dīn, and Islam: A Complex Web. Jinterdisciplinary Journal for Religion and Trans-formation in Contemporary Society. (In Press)

Majeed, Javed. 2009. Muhammad Iqbal: Islam, Aesthetics and Postcolonialism. London, New York and New Delhi: Routledge.

Marei, Fouad Gehad. 2020. Local Coordination Committees. In Conflict in the Modern Middle East: An Encyclopedia of Civil War, Revolutions and Regime Change. Edited by Jonathan K. Zartman. Santa Barbara: ABC-CLIO, pp. 192-93. 
Menghini, Pietro. 2019. Nonviolence in Islam: Jawdat Sa id and the Path of Adam's First Son. Afkar: The Undergraduate Journal of Middle East Studies 1: 49-59.

Müller, Jean-Marie. 2010. Désarmer les dieux: Le christianisme et l'islam face à la non-violence. Paris: Les Editions du Relié.

Murtaza, Mohammed Sameer. 2016. Eine Ethik der Gewaltlosigkeit_Ein Ansatz des syrischen Gelehrten Jawdat Sa'id. In Gewaltfreiheit, Politik und Toleranz im Islam. Edited by Jörgen Klußmann, Muhammad Sameer Murtaza, Holger-C. Rohne and Yahya Wardak. Wiesbaden: Springer VS, pp. 123-39.

Nasr, Seyyed Hossein, Caner K. Dagli, Maria Massi Dakake, Joseph E. B. Lumbard, and Mohammed Rustom, eds. 2015. The Study Quran: A New Translation and Commentary. New York: HarperCollins.

Navas, Eduardo. 2012. Remix Theory: The Aesthetics of Sampling. Wien: Springer.

Ollivry-Dumairieh, Florence. 2016. Jawdat Sa id: Penseur de la non violence en Islam. Ultrë̈a! 9: 132-36.

Omar, Irfan A. 2008a. Towards an Islamic Theology of Nonviolence I: A Critical Appraisal of Maulana Wahiduddin Khan's View of Jihad. Vidyajyoti Journal of Theological Reflection 72: 671-80.

Omar, Irfan A. 2008b. Towards an Islamic Theology of Nonviolence II: A Critical Appraisal of Maulana Wahiduddin Khan's View of Jihad. Vidyajyoti Journal of Theological Reflection 72: 751-58.

Perlman, Wendy. 2019. Civil Action in the Syrian Conflict. Edited by Deborah Avant, Marie Berry, Erica Chenoweth, Rachel Epstein, Cullen Hendrix, Oliver Kaplan and Timothy Sisk. Oxford: Oxford University Press, pp. 35-63.

Rak, Karolina. 2016. Ğawdat Sa `̄id's Thought within the Discourse of Muslim Revival. Hemispheres 31: 33-42.

Sa id, Jawdat. 1984. Work as Ability and Will. Translated by Abdullatif Al-Khaiat. Damascus: Said.

Sa'id, Jawdat. 1993. Madhhab ibn Ādam al-awwal: Mushkilat al-'unf fì' 'amal al-islāmī. Beirut: Dār al-Fikr.

Sa id, Jawdat. 1998. al- 'Ubūdiyya al-mukhtāra: Tahwī al-safha 'alā al-nass al-kāmil li'l-kitāb wa-hija lā tazāl qayd al-tahrīr. Available online: https: / /jawdatsaid.net/index.php?title=\%D8\%A7\%D9\%84\%D8\%B9\%D8\%A8\%D9\%88\%D8\%AF\%D9\%8A\%D8\%A9_\% D8\%A7\%D9\%84\%D9\%85\%D8\%AE\%D8\%AA\%D8\%A7\%D8\%B1\%D8\%A9 (accessed on 27 December 2021).

Sa id, Jawdat. n.d.a Hattā yughaiyyirū mā bi-anfusihim. Available online: https://jawdatsaid.net/index.php?title=\%D8\%AA\%D8\%B5 \%D9\%86\%D9\%8A\%D9\%81:\%D8\%AD\%D8\%AA\%D9\%89_\%D9\%8A\%D8\%BA\%D9\%8A\%D8\%B1\%D9\%88\%D8\%A7_\%D9\%8 5\%D8\%A7_\%D8\%A8\%D8\%A3\%D9\%86\%D9\%81\%D8\%B3\%D9\%87\%D9\%85 (accessed on 28 December 2021).

Sa id, Jawdat. n.d.b Iqra' wa-rabbuka al-Akram. Available online: https://jawdatsaid.net/index.php?title=\%D8\%AA\%D8\%B5\%D9\%8 6\%D9\%8A\%D9\%81:\%D8\%A7\%D9\%82\%D8\%B1\%D8\%A3_\%D9\%88\%D8\%B1\%D8\%A8\%D9\%83_\%D8\%A7\%D9\%84\%D8\%A3 $\%$ D9\%83\%D8\%B1\%D9\%85 (accessed on 28 December 2021).

Sa id, Jawdat. n.d.c Law, Religion and the Prophetic Method of Social Change. Available online: https:/ / karamah.org/law-religionand-the-prophetic-method-of-social-change/ (accessed on 27 December 2021).

Sa id, Jawdat. n.d.d Li-madhā al-lā'unf? Available online: https://jawdatsaid.net/index.php?title=\%D9\%84\%D9\%85\%D8\%A7\%D8 \%B0\%D8\%A7_\%D8\%A7\%D9\%84\%D9\%84\%D8\%A7\%D8\%B9\%D9\%86\%D9\%81 (accessed on 27 December 2021).

Seniguer, Haoués. 2014. La civilisation islamique et l'humanisme arabo-musulman: Le regard de Malek Bennabi. Confluences Méditerranée 89: 187-209. [CrossRef]

Sherif, M. A. 2018. Facets of Faith: Malek Bennabi and Abul A'la Maududi: The Early Life and Selected Writings of Two Great Thinkers of the Twentieth Century. Kuala Lumpur: Islamic Book Trust.

Zecca, Valentina. 2020. Review: Jawdat Said, (2017) Vie islamiche alla non-violenza. Marzabotto-Bologna: Zikkaron. In Jews in Dialogue: Jewish Responses to the Challenges of Multicultural Contemporaneity. Edited by Magdalena Dziaczkowska and Adele Valeria Messina. Leiden and Boston: Brill, pp. 212-16. 